\title{
Revisión / Review \\ Therapeutic potential of medicinal plants against Leishmaniasis: a public health concern
}

[Potencial terapéutico de plantas medicinales contra la Leishmaniasis: Un problema de salud pública]

\author{
Kashif Hussain ${ }^{1}$, Rao Zahid Abbas ${ }^{2}$, Asghar Abbas ${ }^{1}$, Muhammad Asif Raza', Muhammad Shahid Mahmood, \\ Muhammad Imran', Muhammad Kasib Khan ${ }^{2} \&$ Muhammad Rafay ${ }^{4}$
}

${ }^{1}$ Department of Veterinary and Animal Sciences, Muhammad Nawaz Shareef University of Agriculture Multan, Pakistan

${ }^{2}$ Department of Parasitology, University of Agriculture Faisalabad, Pakistan

${ }^{3}$ Institue of Microbiology, University of Agriculture Faisalabad, Pakistan

${ }^{4}$ Department of Forestry, Range and Wildlife Management, The Islamia University of Bahawalpur, Pakistan

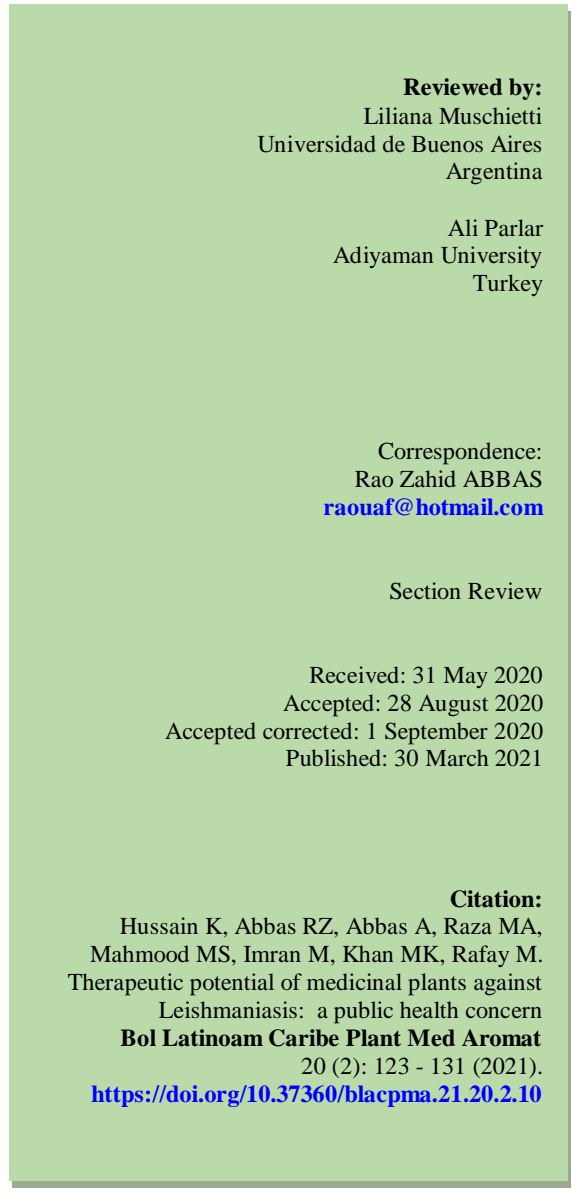

Abstract: Leishmaniasis is an important disease affecting global public health which is spread by sand fly having different species. Various chemical drugs are used to treat and control Leishmaniasis including pentavalent antimonials, antimicrobial and antibiotics. Due to emergence of drug resistance, these therapeutic options are losing effectiveness in attaining success. Furthermore, these drugs are expensive and have toxic effects on liver and kidneys. There has been an emerging interest and excellent response by using plant based drugs and extracts to control Leishmaniasis. Different medicinal plants including Glycyrrhiza glabra, Allium sativum, Peganum harmala and Nigella sativa have shown excellent antileishmanial activity. Therefore, medicinal plants can help in effective drug development against Leishmaniasis diseases in both animals and humans which will be safer and health protective.

Keywords: Medicinal Plants; Leishmaniasis; Health; Treatment; Resistance.

Resumen: La Leishmaniasis es una enfermedad importante que afecta la salud pública mundial y que es transmitida por las moscas de la arena, que tienen diferentes especies. Se utilizan varios medicamentos químicos para tratar y controlar la Leishmaniasis, incluidos los antimoniales pentavalentes, antimicrobianos y antibióticos. Debido a la aparición de resistencia a los medicamentos, estas opciones terapéuticas están perdiendo eficacia para lograr el éxito. Además, estos medicamentos son costosos y tienen efectos tóxicos en hígado y riñones. Ha habido un interés emergente y una excelente respuesta mediante el uso de extractos y medicamentos a base de plantas para controlar la Leishmaniasis. Diferentes plantas medicinales como Glycyrrhiza glabra, Allium sativum, Peganum harmala y Nigella sativa han mostrado una excelente actividad anti-leishmanial. Por lo tanto, las plantas medicinales pueden ayudar en el desarrollo de fármacos eficaces contra las enfermedades de la leishmaniasis tanto en animales como en seres humanos, lo que será más seguro y proteja la salud.

Palabras clave: Plantas medicinales; Leishmaniasis; Salud; Tratamiento; Resistencia. 


\section{INTRODUCTION}

Parasitism is a global problem effecting health of human and animal population all over the world ( $\mathrm{Li}$ et al., 2020; Salman et al., 2020). Parasites have complex lifecycles and have variation in transmission routes. Parasites also act as vector of many important diseases which appose serious threat to public health like Leishmaniasis (Oryan et al., 2015). Leishmaniasis is an important widespread disease affecting both humans and animals which is caused by Leishmania parasites having different species ( $L$. donovani, $L$. major, L. mexicana, L. amazonensis) and is transmitted by vector sand fly of genus Phlebotomus and Lutzomyia. The parasite lives in mononuclear phagocytic cells of vertebrates (Dujardin et al., 2008; $\mathrm{Li}$ et al., 2020). According to World Health Organization, Leishmaniasis is endemic in 88 countries of the world including Middle East, South America, Europe and Asia, and is one of the seven most important tropical diseases with a potentially fatal outcome (Andrade-Narváez et al., 2003). Overall in the world about 12 and 15 million people are infected with Leishmania species. About 350 million people are at risk and each year 1-2 million new cases are reported while 70,000 deaths are attributed to this disease (Bravo \& Sanchez, 2003; Khezzani \& Bouchemal, 2017).

Leishmaniasis mostly occurs in visceral form, known as kala-azar, and cutaneous form which causes serious threats to human health including young children and adult population all over the world. In cutaneous Leishmaniasis form, major clinical signs include severe cutaneous lesions which start in the nasal and oral mucosa and spread to pharynx, larynx, forearms and esophagus (Khezzani \& Bouchemal, 2017). In extreme cases, death may also occur due to pain and atrophy of respiratory mucosa. In visceral Leishmaniasis, black fever lesions may appear in reticuloendothelial system and may include lymphadenopathy, hepatomegaly, splenomegaly, cutaneous pigmentation, weight loss and ultimately death (Desjeux, 2004).

Various drugs are used to treat Leishmaniasis including pentavalent antimonials, antimicrobial and antibiotics (Rezaei et al., 2017). Pentavalent antimonials are used as first line of treatment against cutaneous and visceral Leishmaniasis. The second choice therapeutic agents are amphotericin-B and pentamidine which are used to treat the visceral form (Amato et al., 2008). Unfortunately, commercially available anti-leishmanial drugs are losing their effectiveness mainly because of emergence of resistant strains of Leishmania, furthermore, toxic effects of on human health are additional drawbacks of these drugs (WHO, 2010).

So, exploration of diverse and alternative compounds and therapeutic agents against diseases of public health and livestock is appealing approach (Abbas et al., 2017; Abbas et al.,2019; Afsheen et al., 2019; Ali et al., 2020; Zhang et al., 2020). Among natural agents botanicals and their compounds have shown encouraging therapeutic properties against various parasitic diseases including Leishmaniasis (Townson, 2001; Khare et al., 2014; Mans et al., 2016; Rahman \& Mohsin, 2019).

A considerable work has been reported on the successful development of anti-lesihmanial drugs from medicinal plants. Some previous and recent work is summarized in Table No. 1 .

\section{Anti-leishmanial effects of some important medicinal plants Glycyrrhiza glabra}

Glycyrrhiza glabra belongs to the Fabaceae family and contains glycyrrhizic acid (GA) which has shown anti-leishmanial activity and its mode of action has also been discovered. GA showed dose dependent anti-leishmanial efficacy by inhibiting the promastigotes and intracellular amastigotes stages of the parasites (Dinesh et al., 2017). The results of this study showed that GA inhibits the parasites growth by affecting sterol biosynthetic pathway, especially by inhibiting the enzymatic activity.

\section{Ferula szowitsiana}

More than 133 species belonging to the Apiaceae family are distributed throughout the Mediterranean area and central Asia such as Iran and Afghanistan and most found genus is Ferula (Bafghi et al., 2014). The part used is an oleo gum resin, obtained by incision from the stem and root, and called asafetida, which is used for its anticonvulsant, antispasmodic, carminative, digestive, expectorant, sedative, antihysteric, laxative, aphrodisiac, antiseptic and analgesic activities (Iranshahi et al., 2007). Many Asian countries use this plant against intestinal parasites (Emami et al., 2010). Sesquiterpene coumarins which were isolated from Ferula szowitsiana showed anti-leishmanial effects against the promastigote forms (Iranshahi et al., 2007). 
Table No. 1

Plants reported for their anti-leishmanial activity

\begin{tabular}{|c|c|c|c|c|}
\hline Plants & $\begin{array}{c}\text { Common } \\
\text { Name/English Name }\end{array}$ & Family Name & $\begin{array}{c}\text { Main } \\
\text { Component }\end{array}$ & Reference \\
\hline Allium sativum & Garlic & Amaryllidaceae & Allicin, Alliin & $\begin{array}{l}\text { Ghazonfari et al., } 2000 \\
\text { Shang } \text { et al., } 2019\end{array}$ \\
\hline Allium sativum & Garlic & Amaryllidaceae & Allicin, Alliin & $\begin{array}{c}\text { Ghazonfari et al., } 2000 \\
\text { Shang et al., } 2019\end{array}$ \\
\hline Artemisia absinthium & Wormwood & Asteraceae & Endoperoxide & Azizi et al., 2016 \\
\hline Artemisia absinthium & Wormwood & Asteraceae & Endoperoxide & Azizi et al., 2016 \\
\hline Artemisia aucheri & Artemis & Asteraceae & $\begin{array}{l}\text { Camphene } \\
\beta \text {-Myrcene }\end{array}$ & Sharif et al., 2006 \\
\hline Artemisia aucheri & Artemis & Asteraceae & $\begin{array}{l}\text { Camphene } \\
\beta \text {-Myrcene }\end{array}$ & Sharif et al., 2006 \\
\hline Artemisia dracunculus & Estragon & Asteraceae & $\begin{array}{c}\alpha \text {-Pinene, Myrecene, } \\
\text { Limonene }\end{array}$ & Rezaei et al., 2017 \\
\hline Artemisia dracunculus & Estragon & Asteraceae & $\begin{array}{c}\alpha \text {-Pinene, Myrecene, } \\
\text { Limonene }\end{array}$ & Rezaei et al., 2017 \\
\hline Cassia fistula & Amaltas & Fabaceae & Sterol, clerosterol & $\begin{array}{c}\text { Barati et al., } 2010 \\
\text { Sartorelli et al., } 2007\end{array}$ \\
\hline Cassia fistula & Amaltas & Fabaceae & Sterol, clerosterol & $\begin{array}{c}\text { Barati et al., } 2010 \\
\text { Sartorelli et al., } 2007\end{array}$ \\
\hline Cinnamomum cassia & Cassia & Lauraceae & $\alpha$-Pinene, $\beta$-Pinene & Afrin et al., 2019 \\
\hline Echinacea purpurea & Purple coneflower & Asteraceae & Cichoric acid & Sadati et al., 2011 \\
\hline Echinacea purpurea & Purple coneflower & Asteraceae & Cichoric acid & Sadati et al., 2011 \\
\hline Ferula asafetida & Asafoetida & Apiaceae & $\begin{array}{l}\text { Resin, volatile oil, } \\
\text { Eucalyptol }\end{array}$ & $\begin{array}{l}\text { Alborzi et al., } 2003 \\
\text { Bafghi et al., } 2014\end{array}$ \\
\hline Ferula asafetida & Asafoetida & Apiaceae & $\begin{array}{l}\text { Resin, volatile oil, } \\
\text { Eucalyptol }\end{array}$ & $\begin{array}{l}\text { Alborzi et al., } 2003 \\
\text { Bafghi et al., } 2014 \\
\end{array}$ \\
\hline Ferula szowitsiana & Asafoetida & Apiaceae & $\begin{array}{c}\text { Coumarins, } \\
\text { Phenylpropanoid }\end{array}$ & Iranshahi et al., 2007 \\
\hline Glycyrrhiza glabra & Liquorice & Fabaceae & Glycyrrhizic acid & $\begin{array}{c}\text { Chen } \text { et al., } 1993 \\
\text { Dinesh et al., } 2017\end{array}$ \\
\hline Glycyrrhiza glabra & Liquorice & Fabaceae & Glycyrrhizic acid & $\begin{array}{l}\text { Chen } \text { et al., } 1993 \\
\text { Dinesh } \text { et al., } 2017\end{array}$ \\
\hline $\begin{array}{l}\text { Haplophyllum } \\
\text { bucharicum }\end{array}$ & Sadaap & Rutaceae & Diphyllin & Giorgio et al., 2005 \\
\hline Tasmanian bluegum & Eucalyptus & Myrtaceae & Galic acid & Tahir et al., 1998 \\
\hline Tasmanian bluegum & Eucalyptus & Myrtaceae & Galic acid & Tahir et al., 1998 \\
\hline
\end{tabular}


Table No. 2

Effects of medicinal plants on Leishmania parasite

\begin{tabular}{|c|c|c|c|c|}
\hline Plant Name & Common Name & Family Name & Effects & Refernce \\
\hline Allium sativum & Garlic & Amaryllidaceae & $\begin{array}{l}\text { Destroyed Promastigote } \\
\text { form }\end{array}$ & Gharavi et al., 2011 \\
\hline Aloe latex & Aloe & Asphodelaceae & Effect on growth & Delavari et al., 2013 \\
\hline Artemisia аппиа & wormwood/Gandwash & Asteraceae & $\begin{array}{l}\text { Effective against the } \\
\text { promastigote form }\end{array}$ & Emami et al., 2012 \\
\hline Capsicum annuит & Kapsa & Solanaceae & $\begin{array}{l}\text { Effective against the } \\
\text { promastigote form }\end{array}$ & Yakhchali et al., 2013 \\
\hline Cassia fistula & Amaltas & Fabaceae & $\begin{array}{c}\text { Destroyed the } \\
\text { Promastigote form }\end{array}$ & Barati et al., 2010 \\
\hline Eucalyptus globulus & Blue gum & Myrtaceae & $\begin{array}{l}\text { Reduced cutantaneous } \\
\text { lesions }\end{array}$ & Babaee et al., 2007 \\
\hline $\begin{array}{l}\text { Haplophyllum } \\
\text { bucharicum }\end{array}$ & Sadaap & Rutaceae & $\begin{array}{l}\text { Inhibited growth of } \\
\text { amastigote form }\end{array}$ & Giorgio et al., 2005 \\
\hline Mimosa tenuiflora & Jurema & Fabaceae & $\begin{array}{l}\text { Reduced parasitic } \\
\text { growth }\end{array}$ & Shamsuddini et al., 2006 \\
\hline Nigella sativa & Blach seed & Ranunculaceae & $\begin{array}{l}\text { Reduce the parasitic } \\
\text { growth }\end{array}$ & $\begin{array}{l}\text { Pirali-Kheirabadi et al., } \\
2013\end{array}$ \\
\hline Peganum harmala & Harmal & Nitrariaceae & $\begin{array}{l}\text { Inhibitory effect on } \\
\text { promastigote and } \\
\text { amastigote forms }\end{array}$ & Yousefi et al., 2009 \\
\hline $\begin{array}{c}\text { Stachys } \\
\text { lavandulifolia }\end{array}$ & Wood betony & Lamiaceae & $\begin{array}{l}\text { Inhibitory effect on } \\
\text { promastigotes }\end{array}$ & Naserifard et al., 2013 \\
\hline $\begin{array}{c}\text { Zajuria multiflora } \\
\text { Boiss }\end{array}$ & Thyme & Lamiaceae & $\begin{array}{l}\text { Reduce the parasitic } \\
\text { growth }\end{array}$ & Hejazi et al., 2009 \\
\hline
\end{tabular}

\section{Artemisia annua}

Plants of the Asteraceae family are popular for their various medicinal properties. Artemisinin is a well know antimalarial compound derived from Artemisia апnиa or sweet wormwood. Artemisinin has also been reported for its activity against Leishmania donovani which infects the macrophages and normalizes the nitrite production and mRNA expression, this study showed the parasiticidal and host protective response. In another study, artemisinin has also shown depolarization of the mitochondrial membrane along with a substantial depletion of adenosine triphosphatase (ATP) in Leishmania promastigotes (Heidari et al., 2012; De Sarkar et al., 2019). Furthermore, artemisinin when administered at doses of $10 \mathrm{mg} / \mathrm{kg}$ and $25 \mathrm{mg} / \mathrm{kg}$ of body weight lowered the parasitic burden (Sen et al., 2010).

\section{Cassia fistula}

Cassia fistula belongs to the Fabaceae family. Hexane extract from fruits of Cassia fistula has been reported for its antileishmanial activity against the promastigote forms of Leishmania L. chagasi. $\mathrm{IC}_{50}$ value of $10.03 \mu \mathrm{g} / \mathrm{mL}$ showed inhibitory effect against the promastigote stages of the parasites (Sartorelli et al., 2007). Another study showed that the combination of meglumine antimoniate and Cassia fistula fruit gel was very effective in curing cutaneous Leishmaniasis and proved to be the best choice against cutaneous Leishmaniasis (Jaffary et al., 2010).

\section{Haplophyllum bucharicum}

Haplophyllum bucharicum belongs to Rutaceae family and have shown antiproliferative activity towards human monocytes and Leishmania 
promastigotes by inhibiting the protein synthesis (Giorgio et al., 2005). In an in vitro study, diphyllin isolated from $H$. bucharicum exerted a strong specific inhibitory activity against Leishmania by interference with surface molecules of the promastigote membrane. Diphyllin exerted a strong specific inhibitory activity resulting from the inhibition of parasite internalization within macrophages (Giorgio et al., 2005).

\section{Nauclea diderrichii}

Nauclea diderrichii belongs to Rubiaceae family. Quinovic acid glycosides and the alkaloid cadambine acid have been identified in this plant. Four quinovic acid glycosides and cadambine acid revealed a strong antileishmanial activity $\left(\mathrm{IC}_{50}=1 \mu \mathrm{M}\right)$ highly specific for the intracellular amastigote form of the parasite. Four quinovic acid glycosides and cadambine acid revealed a strong anti-leishmanial activity $\left(\mathrm{IC}_{50}=1\right.$ $\mu \mathrm{M})$ highly specific for the intracellular amastigote form of $L$. infantum. Quinovic acid glycosides were shown to inhibit parasite internalisation by interfering with promastigotes while cadambine acid exerted immunomodulatory activity by inducing $\mathrm{NO}$ production in human macrophages (Lamidi et al., 1995, Giorgio et al., 2006). Another study reveals that quinovic acid glycosides having immunomodulatory activity by inducing NO production in human macrophages and inhibit promastigotes internalization (Ogunkolade et al., 1990). The combination of amphotericin B and cadambine acid used as conventional therapy against Leishmania species (Giorgio et al., 2006).

\section{Portulaca werdermannii}

Plants of Portulacaceae family are distributed all over the world having pharmacological properties such as analgesic, antibacterial, skeletal musclerelaxant, wound-healing, anti- infammatory and a radical scavenger (Askari et al., 2016). In one study, the extracts of Portulaca werdermannii and Portulaca hirsutissima showed in vitro antileishmanial and immunomodulatory effects against $L$ amazonensis and T. cruzi parasite cultures (Costa et al., 2007).

\section{Piper rusbyi}

Piper rusbyi belongs to the Piperaceae family has various bioactive compounds like kavapyrone (7 $\mathrm{R}, 8 \mathrm{~S}$ )-epoxy-5,6-didehydrokavain (Nwaka \& Hudson, 2006) and the chalconeflavokavain B have anti-leishmanial effects (Pérez et al., 2002). All bioactive compounds showed in vitro antileishmanial activity. Likewise, in vivo efficacy of kavapyrone was also shown against cutaneous leishmaniasis.

\section{Artemisia absinthium}

Artemisia absinthium belongs to family Asteraceae, commonly known as wormwood enriched with essential oils (Chamazulene, nuciferol butanoate, nuciferol propionate, caryophyllene oxide, phellandrene, pinene, azulene -thujone) and phenolic compounds like syringic, chlorogenic, caffeic acid, ferulic acid which have diverse biological properties (Cefalu et al., 2008). They are known to have diverse antiparasitic, antibacterial, antifungal, antidepressant and cytotoxic. Anti-parasitic apoptotic effect was seen at high concentrations of $A$. absinthium against promastogote L. major (Azizi et al., 2016). In another study, essential oil of $A$. Absinthium showed in vitro inhibitory effect on promastigote form of $L$. major. The essential oil of $A$. Absinthium also reduced the progression of lesions (Khanjani et al., 2015).

\section{Artemisia dracunculus}

Artemisia dracunculus (Tarragon) from the Asteraceae family contains artemisinin compounds, have antiparasitic effects due to endoperoxide groups (Mueller et al., 2004). In a recent study, the in vitro anti-leishmanial effect of the extract of Artemisia dracunculus was evaluated and compared to control treatment with pentavalent antimony (meglumine). Results of study revealed that all concentrations significantly reduced the number of promoastigotes of $L$. major with an efficacy of more than $50 \%$ at 10 $\mu \mathrm{g} / \mathrm{mL}$ (Rezaei et al., 2017).

\section{Urtica dioica}

Urtica dioica commonly known as stinging nettle belongs to family Urticaceae is enriched with many active compounds including tannins and glucoside compounds. Urtica dioica has been used as anticancerous, anti-inflammatory, antirheumatic and antioxidant agent (Bourgeois et al., 2016). In a recent study, aqueous extract of Urtica dioica killed the L. major amastigotes. In addition, the lesion size and parasite load were decreased in the treated infected mice (Badirzadeh et al., 2020).

\section{Mechanism of action of medicinal plants}

Natural compounds obtained from different parts of plants (leaves, roots, fruits or seeds) are commonly used in medicine to treat Leishmaniasis (Colares et 
al., 2013). These compounds act against Leishmania by different mechanisms. Some medicinal plants are enriched with esssential oils which are composed of different hydrophobic molecules (sesquiterpenes and terpenes, monoterpenes) which can diffuse easily across cell membranes and consequently gain access to intracellular targets (Colares et al., 2013; Machado et al., 2014). Terpenes can easily penetrate the lipid bilayer of cell membrane and produce changes in the integrity of cell structures and mitochondrial membrane of Leishmania parasite (Colares et al., 2013). Furthermore, the active ingredients in some plant extracts such as diphyllin isolated from Haplophyllum bucharicum are involved in interaction with macromolecules and lead to cell cycle arrest and inhibition of protein synthesis of parasite (Giorgio et al., 2005). Plants enriched with antioxidant compounds such as flavonoids (catechins) are able to form complexes with the parasite cell wall and hence inhibit the parasitic growth. Artemisinin present in Artemesia annua plant causes depolarization of the mitochondrial membrane along with a substantial depletion of adenosine triphosphatase (ATP) (Ogeto et al., 2013; De Sarkar et al., 2019).

\section{Concluding Remarks}

Leishmaniasis is a neglected disease affecting a large human population with fatal outcome. Given the fact that anti-leishmanial vaccines may not become available in the near future, the search for better drugs should be continued. Due to drug resistance and toxic effects of synthetic drugs on health, this method is not much appealing. Natural products may offer an unlimited source of chemical diversity to identify new drugs against Leishmaniasis. Different medicinal plants as reported in this review have shown therapeutic effects and have potential in effective drug development against Leishmaniasis disease. Exploration of different medicinal plants can provide a better solution to control this severe disease and can play an important role in addressing public health issue.

\section{REFERENCES}

Abbas A, Abbas RZ, Khan MK, Raza MA, Mahmood MS, Saleemi MK, Hussain T, Khan JA, Sindhu ZD. 2019. Anticoccidial effects of Trachyspermum ammi (Ajwain) in broiler chickens. Pak Vet J 39: 301 - 304. https://doi.org/10.29261/pakvetj/2019.056

Abbas A, Iqbal Z, Abbas RZ, Khan MK, Khan JA, Sindhu ZuD, Mahmood MS and Saleemi MK. 2017. In vivo anticoccidial effects of Beta vulgaris (sugar beet) in broiler chickens. Microb Path 111: 139 - 144. https://doi.org/10.1016/j.micpath.2017.07.052

Afrin F, Chouhan G, Islamuddin M, Want MY, Ozbak HA, Hemeg HA. 2019. Cinnamomum cassia exhibits antileishmanial activity against Leishmania donovani infection in vitro and in vivo. PLOS Negl Trop Dis 1 - 28. https://doi.org/10.1371/journal.pntd.0007227

Afsheen N, Rehman KU, Jahan N, Khan KM, Zia MA. 2019. Optimization of cardioprotective potential of various concentrations of medicinal plants by using response surface methodology. Pak Vet J 39: 13 - 18. https://doi.org/10.29261/pakvetj/2018.111

Alborzi A, Namjoian F, Azadbakht M, Obodi B, Panjehshahin M, Rasoli M. 2003. Effects of Ferula assa-foetida and its effective fractions on Leishmania (in vitro). Infect Tropic Dis Iran 8: 36 - 40.

Ali S, Ijaz M, Ahmed A, Aziz MU, Naveed M, Javed MU, Nawab Y, Ghumman NZ, Ghaffar A. 2020. Prevalence and associated risk factors of bovine babesiosis in Lahore, Pakistan. Agrobiol Records 2: 17 - 23. https://doi.org/10.47278/journal.abr/2020.009

Amato VS, Tuon FF, Bacha HA, Neto VA, Nicodemo AC. 2008. Mucosal leishmaniasis current scenario and prospects for treatment. Acta Trop 1: 105 - 109. https://doi.org/10.1016/j.actatropica.2007.08.003

Andrade-Narváez FJ, Vargas-González A, Canto-Lara SB, Damián-Centeno AG. 2003. Clinical picture of cutaneous leishmaniases due to Leishmania (Leishmania) in the Yucatan peninsula. Mem Inst Oswaldo Cruz 96: 163 - 1677. https://doi.org/10.1590/s0074-02762001000200005

Askari VR, Rezaee SA, Abnous K, Iranshahi M, Boskabady MH. 2016. The influence of hydro- ethanolic extract of Portulacaoleracea L. on T1/T2 balance in isolated human lymphocytes. J Ethnopharmacol 194: 1112 1121. https://doi.org/10.1016/j.jep.2016.10.082

Azizi K, Shahidi-Hakak, F, Asgari Q, Hatam GR, Fakoorziba MR, Miri R. Moemenbellah-Fard MD. 2016. In vitro efficacy of ethanolic extract of Artemisia absinthium (Asteraceae) against Leishmania major L. using cell sensitivity and flow cytometry assays. J Parasitic Dis 40: 735 - 740.

https://doi.org/10.1007/s12639-014-0569-5

Babaee KL, Mohebali M, NiakanLahiji MR, MehrabiTavana A. 2007. The therapeutic effect of Eucalyptus, 
Myrtus, Ferula, Aretmisia, Allium and Urtica extracts against cutaneous Leishmaniasis caused by Leishmanaia major in small white mice (outbred). Hakim Res J 10: 21 - 27.

Badirzadeh A, Heidari-Kharaji M, FallahOmrani V, Dabiri H, Araghi A, Salimi CA. 2020. Antileishmanial activity of Urtica dioica extract against zoonotic cutaneous leishmaniasis. PLoS Negl Trop Dis 14: e0007843. https://doi.org/10.1371/journal.pntd.0007843

Bafghi AF, Bagheri SM, Hejazian SH. 2014. Antileishmanial activity of Ferula assa-foetida oleo gum resin against Leishmania major: An in vitro study. J Ayurveda Integr Med 5: 223 - 226. https://doi.org/10.4103/0975-9476.146567

Barati M, Sharifi I, Sharififar F. 2010. Antileishmanial activity of Artemisia aucheri, Ferula assafoetida and Gossypium hirsutum extracts on Leishmania major promastigotes in vitro. Ann Mil Health Sci Res 8: 166 - 172. https://doi.org/10.2174/22113525113119990005

Bourgeois C, Leclerc EA, Corbin C, Doussot J, Serrano V, Vanier JR. 2016. Nettle (Urtica dioica L.) as a source of antioxidant and anti-aging phytochemicals for cosmetic applications. Comptes Rendus Chimie 19: 1090 1100. https://doi.org/10.1016/j.crci.2016.03.019

Bravo F, Sanchez MR. 2003. New and re-emerging cutaneous infectious diseases in Latin America and other geographic areas. Dermatol Clin 21: 655 - 668. https://doi.org/10.1016/s0733-8635(03)00090-1

Cefalu WT, Ye J, Zuberi A, Ribnicky DM, Raskin I, Liu Z, Wang ZQ, Brantley PJ, Howard L, Lefevre M. 2008. Botanicals and the metabolic syndrome. Am J Clin Nutr 87: 481s - 487s. https://doi.org/10.1093/ajen/87.2.481s

Chen M, Christensen SB, Blom J, Lemmich E, Nadelmann L, Fich K, Lichochalcone A. 1993. A novel antiparasitic agent with potent activity against human pathogenic protozoan species of leishmania. Antimicrob Agents Chemother 37: 2550 - 2556. https://doi.org/10.1128/aac.37.12.2550

Colares AV, Almeida-Souza F, Taniwaki NN, Souza SC, da Costa JG, Calabrese KS, Abreu-Silva AL. 2013. In vitro antileishmanial activity of essential oil of Vanillosmopsis arborea (Asteraceae) baker. Evid Based Complement Alternat Med 2013: 727042. https://doi.org/10.1155/2013/727042

Costa JFO, Kiperstok AC, David JPL, David JM, Giulietti AM, Queiroz LP. 2007. Anti-leishmanial and immunomodulatory activities of extracts from Portulaca hirsutissima and Portulaca werdermannii. Fitoterapia 78: 510 - 514. https://doi.org/10.1016/j.fitote.2007.05.005

Delavari M, Dalimi Asl A, Ghaffarifar F, Sadraei J. 2013. Effect of aloeemodin on growth and induction of apoptosis in Leishmania major promastigotes in vitro. J Kashan Univ Med Sci 17: 422 - 428.

Desjeux P. 2004. Leishmaniasis: current situation and new perspectives. Comp Immunol Microbiol Infect Dis 27: $305-318$.

De Sarkar S, Sarkar D, Sarkar A, Dighal A, Chakrabarti S, Staniek K, Gille L, Chatterjee M. 2019. The leishmanicidal activity of artemisinin is mediated by cleavage of the endoperoxide bridge and mitochondrial dysfunction. Parasitology 146: 511 - 520. https://doi.org/10.1017/s003118201800183x

Dinesh N, Neelagiri S, Kumar V, Singh S. 2017. Glycyrrhizic acid attenuates growth of Leishmania donovani by depleting ergosterol levels. Parasitology 176: 21 - 29. https://doi.org/10.1016/j.exppara.2017.02.015

Dujardin J, Campino L, Boelaert M. 2008. Spread of vector-borne diseases and neglect Leishmaniasis, Europe. Emerg Infect Dis 14: 1013 - 1018. https://doi.org/10.3201/eid1407.071589

Emami SA, Rabe SZT, Iranshahi M, Ahi A, Mahmoudi M. 2010. Sesquiterpene lactone fraction from Artemisia khorassanica inhibits inducible nitric oxide synthase and cyclooxygenase-2 expression through the inactivation of NF-kappaB. Immunopharmacol Immunotoxicol 32: 688 - 695. https://doi.org/10.3109/08923971003677808

Emami SA, TaghizadehRabe SZ, Ahi A, Mahmoudi M. 2012. Inhibitory activity of eleven Artemisia species from Iran against Leishmania major parasites. Iran J Basic Med Sci 15: 807 - 811.

Gharavi M, Nobakht M, Khademvatan S, Fani F, Bakhshayesh M, Roozbehani M. 2011. The effect of aqueous garlic extract on interleukin-12 and 10 levels in Leishmania major (MRHO/IR/75/ER) infected macrophages. Iran J Public Health 40: 105 - 111.

Ghazonfari T, HassaniZ, Ebtekar M, Ahmadiani M, Naderi AG, Azar A. 2000. Garlic induces a shift in a Leishmania major - infected balby mice. Scand J Immunol 52: 491 - 495.

https://doi.org/10.1046/j.1365-3083.2000.00803.x

Giorgio CD, Delmas F, Akhmedjanova V, Ollivier E, Bessonova I, Riad E, Pierre David PT. 2005. In vitro antileishmanial activity of diphyllin isolated from Haplophyllum bucharicum. Planta Med 71: 366 - 369. 
https://doi.org/10.1055/s-2005-864106

Giorgio CD, Lamidi M, Delmas F, Guy Balansard G, Ollivier E. 2006. Antileishmanial activity of quinovic acid glycosides and cadambine acid isolated from Nauclea diderrichii. Planta Med 72: 1396 - 1402. https://doi.org/10.1055/s-2006-951726

Heidari FI, Ghaffarifar F, Dalimi A, Dehkordi NM, Nikoo SG. 2012. In vitro study of the effect of artimisinin on promastigotes and amastigotes of Leishmania major. Modares J Med Sci Pathobiol 15: 33-43.

Hejazi SH, Shirani-Bidabadi L, Zolfaghari-Baghbaderani A, Saberi S, Nilforoushzadeh MA, Moradi SH. 2009. Comparison effectiveness of extracts of Thyme, yarrow, henna and garlic on cutaneous leishmaniasis caused by L. major in animal model (Balb/c). J Med Plants 8: 129 - 136.

Iranshahi M, Arfa P, Ramezani M, Jaafari MR, Sadeghian H, Bassarello C. 2007. Sesquiterpene coumarins from Ferula szowitsiana and in vitro antileishmanial activity of 7-prenyloxycoumarins against promastigotes. Phytochemistry 68: 554 - 561. https://doi.org/10.1016/j.phytochem.2006.11.002

Jaffary F, Nilforoushzadeh MA, Ansari N, Rahimi M. 2010. Treatment of cutaneous leishmaniasis: Cassia fistula fruit gel-intralesional glucantime Vs. placebo gel-intralesional glucantime combination. Tehran Univ Med J 67: 705 - 711.

Khare P, Rastogi P, Gupta S, Maurya R, Dube A. 2014. In vitro and in vivo efficacy of a new herbaceous indian plant Abutilon indicum Leishmania against Leishmania donovani infection. Am J Phytomed ClinTher 2: $134-139$.

Khanjani JS, Farazmand A, Amin MDA, Shirzadi MR, Razavi MR. 2015. Methanolic extract's activity of Artemisia absinthium, Vitexagnus-castus and Phytolaca americana against Leishmania major; in vitro and in vivo. Int Arch Health Sci 2: 69 - 74.

Khezzani B, Bouchemal S. 2017. Demographic and spatio-temporal distribution of cutaneous leishmaniasis in the Soufoasis (Eastern South of Algeria): Results of 13 years. ActaTropica 166: 74 - 80. https://doi.org/10.1016/j.actatropica.2016.11.012

Lamidi M, Ollivier E, Faure R, Debrauwer L, Nze-Ekekang L, Balansard G. 1995. Quinovic acid glycosides from Naucleadi derrichii. Planta Med 61: 280 - 281. https://doi.org/10.1055/s-2006-958075

Li K, Zhang L, Luo H, Mehmood K, Shahzad M, Naseer MU. 2019. Besnoitiosis: an emerging parasitic disease in yaks (bos grunniens) and tibetan sheep (ovies aries) on the qinghai tibetan plateau, China. Pak Vet J 39: 447 - 450. https://doi.org/10.29261/pakvetj/2019.086

Li K, Luo H, Mehmood K, Shahzad M, Li J, 2020. Exploring the potential parasitic pathogens causing diarrheal death to yak calves with bloody excrement through high-throughput sequencing. Agrobiol Records 1: 1 5. https://doi.org/10.47278/journal.abr/2020.002

Machado M, Dinis AM, Santos-Rosa M, Alves V, Salgueiro L, Cavaleiro C, Sousa MC. 2014. Activity of Thymus capitellatus volatile extract, 1,8-cineole and borneol against Leishmania species. Vet Parasitol 200: 39 49. https://doi.org/10.1016/j.vetpar.2013.11.016

Mans DRA, Beerens T, Magali I, Soekhoe RC, Schoone GJ, Oedairadjsingh K, Hasrat JA, van den Bogaart E, Schallig HDFH. 2016. In vitro evaluation of traditionally used Surinamese medicinal plants for their potential anti-leishmanial efficacy. J Ethnopharmacol 180: 70 - 77. https://doi.org/10.1016/j.jep.2016.01.012

Mueller MS, Runyambo N, Wagner I, Borrmann S, Dietz K, Heide L. 2004. Randomized controlled trial of a traditional preparation of Artemisia annua L. (annual wormwood) in the treatment of malaria. Trans R Soc Trop Med Hyg 98: 318 - 321. https://doi.org/10.1016/j.trstmh.2003.09.001

Naserifard R, Asl AD, Ahmadi N. 2013. Influence of aqueous extract Scrophularia striata on growth of Leishmania major in mice peritoneal macrophages (BALB/c). Res Med 36: 12 - 18.

Nwaka S, Hudson A. 2006. Innovative lead discovery strategies for tropical diseases. Nature Rev Drug Discov 5: 941 - 955. https://doi.org/10.1038/nrd2144

Ogeto TK, Odhiambo RA, Shivairo RS, Muleke CI, Osero BO, Anjili C, Ingonga JM, Osuga IM. 2013. Antileishmanial activity of Aloe secundiflora plant extracts against Leishmania major. Adv Life Sci Tech 13: 9 - 18.

Ogunkolade BW, Colomb-Valet I, Monjour L, Rhodes-Feuillette A, Abita JP, Frommel D. 1990. Interactions between the human monocytic leukaemia THP1 cell line and old and new world species of Leishmania. Acta Trop 47: 171 - 176. https://doi.org/10.1016/0001-706x(90)90023-s

Oryan A, 2015. Plant-derived compounds in treatment of leishmaniasis. Iranian J Vet Res 16: 1 - 19. 
Pérez-Victoria JM, Di Prieto A, Barron D, Ravelo AG, Castanys S, Gamarro F. 2002. Multidrug resistance phenotype mediated by the P-glycoprotein-like transporter in Leishmania: a search for reversal agents. Curr Drug Targets 3: 311 - 333. https://doi.org/10.2174/1389450023347588

Pirali-Kheirabadi KH, Dehghani-Samani A, Adel M, Hoseinpour F. 2013. The effect of essential oil of Nigella sativa and Satureia hortensis on promastigot stage of Lishmania major. Armaghan Danesh J 18: 687 698.

Rahman SU, Mohsin M. 2019. The under reported issue of antibiotic-resistance in foodproducing animals in Pakistan. Pak Vet J 39: 323 - 328.

Rezaei R, Hazrati K, Seyyedi S, Mikaili P. 2017. The anti-leishmanial efficacy of Artemisia dracunculus ethanolic extract in vitro and its effects on IFN-gamma and IL-4 response. Iran J Parasitol 12: 398 - 407.

Sadati MS, Sarkari B, Asgari Q, Hatami S, Tavakl E. 2011. The effect of Echinacea purpurea on cutaneous leishmaniasis in mice infected with Leishmania major. Armaghane Danesh 16: 31 - 40.

Salman S, Zahid RZ, Israr M, Abbas A, Mehmood KM, Khan MK, Sindhu ZD, Hussain R, Saleemi MK, Shah S. 2020. Repellent and acaricidal activity of essential oils and their components against Rhipicephalus ticks in cattle. Vet Parasitol 283: 109178. https://doi.org/10.1016/j.vetpar.2020.109178

Şandru CD, Niculae M, Popescu S, Paştiu AI, Pall E, Spınu M. 2016. Urtica dioica alcoholic extract increases the cell-mediated innate immune potential in chickens. Ind Crop Prod 88: 48 - 50. https://doi.org/10.1016/j.indcrop.2016.02.032

Sartorelli P, Andrade SP, Melhem MSC, Prado FO, Tempone AG. 2007. Isolation of antileishmanial sterol from the fruits of Cassia fistula using bioguided fractionation. Phytother Res 21: 644 - 647. https://doi.org/10.1002/ptr.2131

Sen R, Ganguly S, Saha P, Chatterjee M. 2010. Efficacy of artemisinin in experimental visceral Leishmaniasis. Int J Antimicrob Agents 36: 43 - 49. https://doi.org/10.1016/j.ijantimicag.2010.03.008

Shamsuddini S, Rajab Alian S, Mirzayi M, Boroufiei M. 2006. Efficacy of Mimosa tenuiflora extract on growth of Leishmania protozoa in vitro. Iran J Dermatol 9: 175 - 180.

Shang A, Cao SY, Xu XY, Gan RY, Tang GY, Corke H, Mavumengwana V, Li HB. 2019. Bioactive compounds and biological functions of garlic (Allium sativum L.). Foods 5: 246. https://doi.org/10.3390/foods8070246

Sharif M, Ziaei H, Azadbakht M, Daryani A, Ebadattalb A, Rostami M. 2006. Effect of methanolic extract of Artemisia auchori and Camellia sinensis on Leishmania major (in vitro). Turk Sci 36: 365 - 369.

Tahir AE, Ibrahim AM, Satti GMH, Theander TG, Kharazmi A, Khslid AS. 1998. The potential antileishmanial activity of some Sudanse medicinal plants. Phytother Res 12: 576 - 579.

https://doi.org/10.1002/(sici)1099-1573(199812)12:8<576::aid-ptr354>3.0.co;2-\#

Townson S. 2001. Antiparasitic properties of medicinal plants and other naturally occurring products. Adv Parasitol 50: 199 - 295. https://doi.org/10.1016/s0065-308x(01)50032-9

WHO, 2010. Control of Leishmaniases. WHO Technical Report series, Geneva, Switzerland.

Yakhchali M, Ranjbari-Kijandabeh M. 2013. Effects of Nerium oleander leaf, Ricinus communis oil, Capsicum spp. seeds, and almond compound on cutaneous leishmaniasis caused by Leishmania species under laboratory condition and its effect on cutaneous lesion progression in mice. Sci J Kurdistan Univ Med Sci 18: 13 19.

Yousefi R, Ghaffarifar F, Dalimi Asl A. 2009. The effect of Alkanna tincturia and Peganum harmala extracts on Leishmania major (MRHO/IR/75/ER) in vitro. Iran J Parasitol 4: 40 - 47.

Zhang K., Li X, Na C., Abbas A, Abbas RZ, Zaman MA. 2020. Anticoccidial effects of Camellia sinensis (green tea) extract and its effect on blood and serum chemistry of broiler chickens. Pak Vet J 40: 77 - 80. https://doi.org/10.29261/pakvetj/2019.119 